\title{
QUO VADIS MATERI PESAWAT SEDERHANA DALAM PEMBELAJARAN IPA SEKOLAH DASAR DI ERA DISRUPSI
}

\author{
Siti Fatonah dan Muhammad Shaleh Assingkily \\ Universitas Islam Negeri Sunan Kalijaga Yogyakarta \\ e-mail: siti.fatonah@uin-suka.ac.id, assingkily27@gmail.com
}

\begin{abstract}
Abstrak
Tujuan penelitian ini adalah mengkaji dan mempertanyakan peran materi pesawat sederhana dalam pembelajaran IPA jenjang MI/SD di era disrupsi. Metode penelitian menggunakan pendekatan kualitatif melalui studi kasus dengan observasi, dokumentasi dan semi-structured interview terhadap guru IPA SMP/MTs di Kalimantan Tengah kemudian data dianalisis secara deskriptif melalui studi kepustakaan. Hasil penelitian ini menunjukkan bahwa materi pesawat sederhana urgen dan bermanfaat diedukasi pada peserta didik MI/SD di era disrupsi saat ini. Ditinjau dari perkembangan, kegunaan, dan perannya di era disrupsi, materi pesawat sederhana (tuas, bidang miring, katrol, dan roda berporos) memberikan edukasi kepada peserta didik berupa prinsip kemudahan dan tidak instan. Selanjutnya, kajian pesawat sederhana relevan dengan tantangan yang dapat dijadikan peluang di era disrupsi, meliputi upaya meng-upgrade kualitas kurikulum, penanaman pendidikan nilai, kesadaran perubahan zaman, dan menemukan jati diri.
\end{abstract}

Kata kunci: Era Disrupsi, Pembelajaran IPA, Pesawat Sederhana

\section{Abstract}

This study aims to examine the role of simple aircraft material in learning science at the MI / SD (elementary school) level in the era of disruption. The study uses qualitative approach through case studies with observation, documentation and semi-structured interviews on IPA (natural science) teachers of Middle School / MTs in Central Kalimantan then the data are analyzed descriptively through library research. The results of this study indicate that simple aircraft material is useful to be taught to elementary school students in the current era of disruption. When it is analyzed from the development, usability, and its role in the era of disruption, simple aircraft materials (levers, incline, pulleys, and pivot wheels) provide education to students in the form of ease and not instant principles. Furthermore, the study of simple aircraft is relevant to the challenges that can be used as opportunities in the era of disruption, as an effort to upgrade the quality of the curriculum, educational values, awareness of the changing time and in finding identity.

Keywords: Era of Disruption, Natural Science Learning, Simple Aifcraft

\section{PENDAHULUAN}

Pesawat sederhana merupakan materi sains yang diberikan sejak MI/SD kepada peserta didik. Konsep penyajian materi ini, lazim diajarkan dengan praktik di kelas maupun laboratorium IPA (Tartiwi \& Wijayanti, 2018). Begitupun, materi tersebut seringkali didekatkan pada kehidupan sehari-hari. Dengan demikian, kemudahan yang diperoleh dari materi ini dapat membantu pekerjaan manusia. Secara umum, pesawat sederhana berfungsi 
sebagai perantara "kemudahan" dan mempercepat aktivitas manusia (Anwar, 2012). Hal ini terlihat dari kegunaan pesawat sederhana selama ini, semisal dalam upaya menimba air dari telaga atau sumur, maka katrol memudahkan manusia menarik ember berisi air. Hal serupa juga terlihat dalam penggunaan gunting atau pisau untuk memotong sesuatu. Keberadaan pesawat sederhana, sejatinya membantu peserta didik dalam menalar materi sains melalui benda-benda (kategori pesawat sederhana). Sebab, peserta didik dibekali teori yang menunjukkan cara kerja dari suatu benda. Bahkan, peserta didik dapat diajak mempraktikkan pembuatan beberapa jenis benda pesawat sederhana.

Pertanyaannya, apakah kajian pesawat sederhana relevan dengan era disrupsi saat ini? Bukankah kemajuan teknologi lebih mempermudah aktivitas manusia? Lantas, Quo Vadis materi pesawat sederhana dalam pembelajaran IPA jenjang MI/SD di era disrupsi? Uraian jawaban dari pertanyaan ini sejatinya mengungkap sejauh mana peranan pesawat sederhana di era disrupsi saat ini.

Era disrupsi ditandai melalui kemajuan teknologi dan kemudahan informasi (Ghufron, 2018). Bila diselaraskan, maka pesawat sederhana memiliki fungsi yang sama. Begitupun, karakteristik era disrupsi berupa volatility, uncertainty, complexity, dan ambiguity (Diana, et.al., 2020), menampilkan perbedaan dengan pesawat sederhana. Hal ini terlihat dari cara kerja benda kategori pesawat sederhana dalam membantu aktivitas manusia sehari-hari.

Penelaahan riset mutakhir terkait pesawat sederhana, menunjukkan bahwa sudah begitu banyak dikaji oleh para peneliti. Di antaranya mengkaji tentang pengembangan model pembelajaran (Hager, et.al., 2012: 1-23; Permatasari, et.al., 2018: 116-127; Iman, et.al., 2017: 52-58; Anwar, 2012; Oktaviana, et.al., 2018: 46-56; Candra, et.al., 2019: 31-34; Pratiwi, et.al., 2017), media pembelajaran (Asmadji, 2013: 1-14; Octafiana, et.al., 2018: 168175; Matsun, et.al., 2019: 30-40; Naimah, et.al., 2017), metode belajar (Suak, et.al., 2016), konsep pesawat sederhana (Zakwandi, 2017: 21-34), alat peraga pesawat sederhana (William, et.al., 2003: 1-12; Rianto, et.al., 2014; Janah, 2016: 1-5), dan prestasi (Widaryanto, 2017) dan hasil belajar peserta didik (Yunidar, 2018; Sayekti, 2018; Asmawir, 2016; Suyanto, 2018) dengan materi pesawat sederhana.

Berdasarkan kajian relevan di atas, penting menganalisa sejauh mana peranan materi pesawat sederhana dalam aktivitas keseharian anak di era disrupsi ini. hal ini terbingkai dalam kata "quo vadis", (mau dibawa ke mana?) kajian pesawat sederhana di era "serba canggih" saat ini. Untuk itu, penelitian ini menelaah materi pesawat sederhana dalam pembelajaran IPA di MI/SD. Lantas, masih relevankah kajian tersebut dengan era kemudahan dan kemajuan yang ditunjukkan saat ini? menganalisa itu, maka diuraikan jenis pesawat sederhana dan contohnya, serta Quo Vadis materi tersebut dengan era disrupsi. 


\section{METODE}

Penelitian ini termasuk penelitian kualitatif dengan metode studi kepustakaan. Buku dan artikel ilmiah merupakan sumber literasi utama dalam riset ini. Penelitian ini menggunakan 7 buku dan 30 artikel ilmiah yang telah terindeks Google Scholar, DOAJ, Springer dan SINTA. Objek kajian terfokus pada analisa buku dan sumber literasi terkait materi pesawat sederhana dalam pembelajaran IPA dan relevansinya dengan era disrupsi dengan revolusi industri 4.0 saat ini. Analisis data dilakukan dengan mengkaji peranan dan relevansi materi pesawat sederhana di era disrupsi. Dengan demikian, penelitian ini dapat menemukan perkembangan, kegunaan, serta peran pesawat sederhana di era disrupsi saat ini. Untuk itu, pengecekan data dalam penelitian ini dilakukan dengan menggunakan bahan pustaka/referensi (Prastowo, 2014).

Mencermati uraian di atas, secara sederhana kerangka alur riset Quo Vadis materi pesawat sederhana dalam pembelajaran IPA jenjang MI/SD di era disrupsi, dapat dilihat dalam skema di bawah ini.

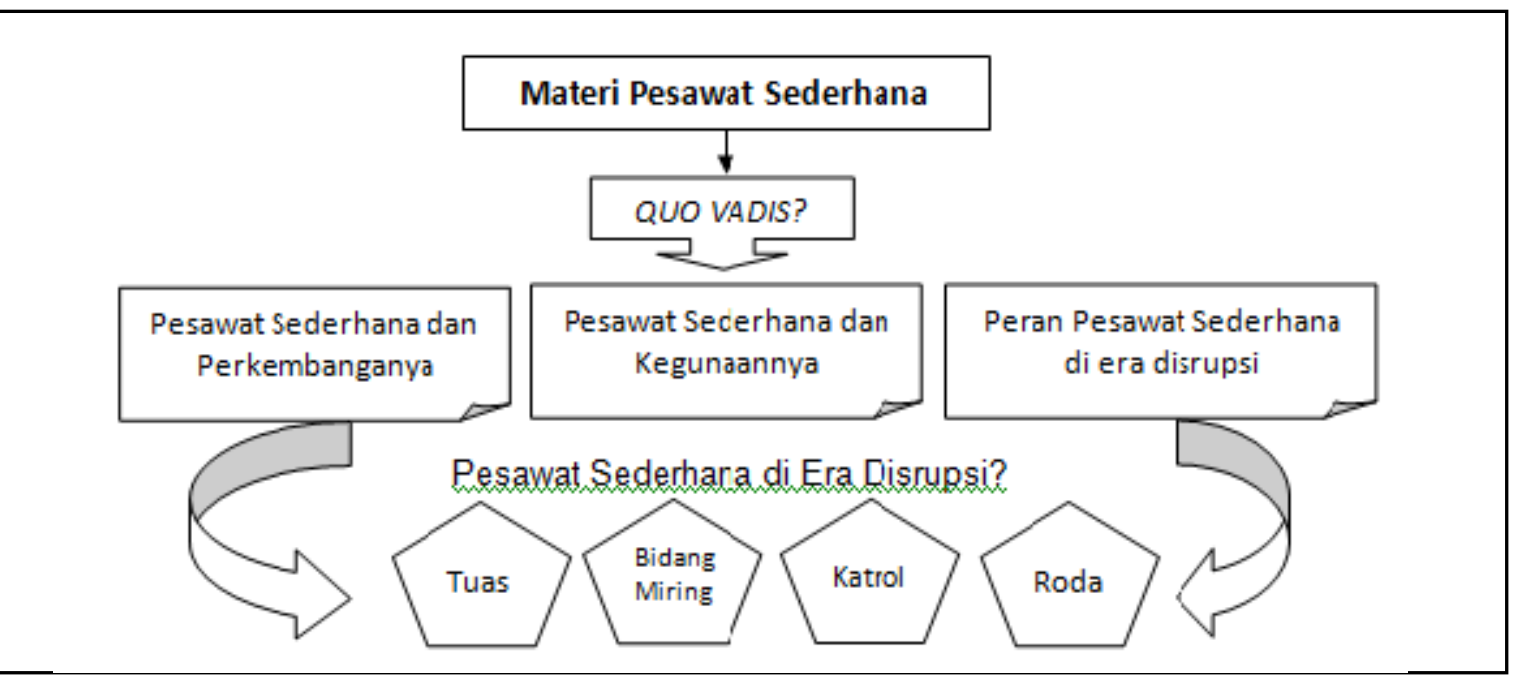

Gambar 1. Skema Alur Riset

\section{HASIL DAN PEMBAHASAN}

Penelitian ini mengkaji tentang 3 aspek dari pesawat sederhana, yakni (1) perkembangan, (2) kegunaan dan (3) peran pesawat sederhana di era disrupsi. Adapun temuan riset ini menunjukkan bahwa berdasarkan tinjauan ketiga aspek tersebut, materi pesawat sederhana memberikan edukasi kepada peserta didik berupa prinsip kemudahan, tidak instan. Selanjutnya, materi pesawat sederhana relevan dengan tantangan yang dapat dijadikan peluang di era disrupsi, meliputi upaya meningkatkan kualitas kurikulum, penanaman pendidikan nilai, kesadaran perubahan zaman, dan menemukan jati diri. 
Dengan demikian, materi pesawat sederhana penting dan bermanfaat diedukasi kepada peserta didik jenjang MI/SD di era disrupsi. Lebih lanjut, deskripsi temuan riset dapat dilihat pada Gambar 2.

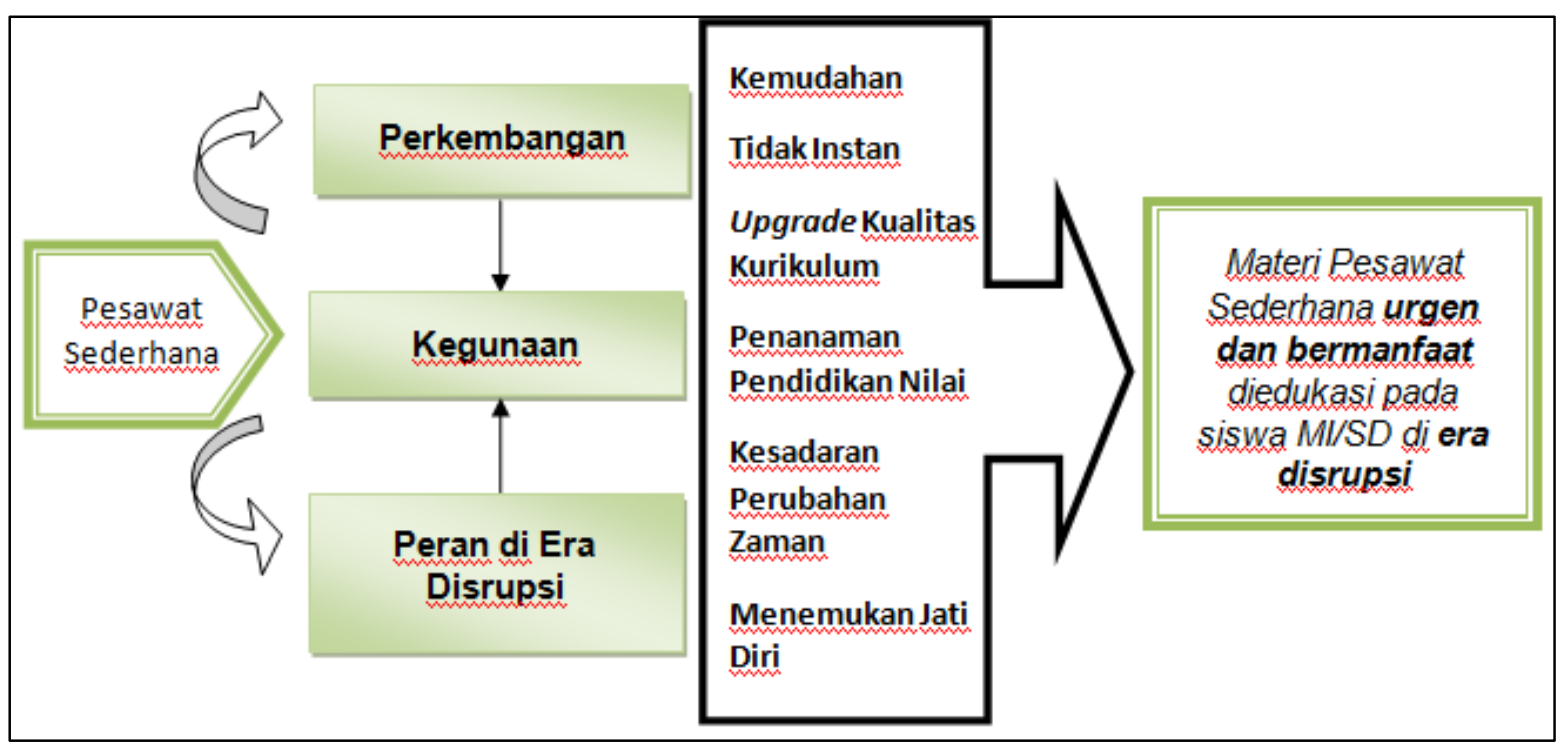

Gambar 2. Peran Pesawat Sederhana di Era Disrupsi

Pesawat sederhana terdiri dari kata "pesawat" dan "sederhana". Kata pesawat dimaknai sebagai peralatan yang dapat membantu kemudahan dan mempercepat aktivitas manusia. Sedangkan kata "sederhana" ditujukan pada penggunaan alat-alat tersebut yang sederhana, atas dasar itu disebutlah sebagai "pesawat sederhana". Pesawat sederhana merupakan salah satu dampak mula-mula dari kemajuan serta perkembangan sains dan teknologi. Begitupun, perkembangan sains menjadi perihal penting dalam era teknologi saat ini. Sehingga, analogi logis dalam hal ini menunjukkan bahwa pesatnya kemajuan teknologi saat ini tidak terpisah dari perkembangan sains (Nash, 1963).

Sejatinya, pesawat sederhana terdiri atas susunan alat sederhana untuk membantu aktivitas keseharian (Marti, 2012). Lebih lanjut, Haryanto (2007) menegaskan bahwa dalam perkembangannya, pesawat sederhana bukanlah didesain untuk menciptakan atau menyimpan gaya, melainkan untuk memudahkan pelaksanaan pekerjaan, meskipun butuh waktu yang lebih lama sebab menempuh lintasan yang lebih jauh. Pengalaman dan kebiasaan penggunaan pesawat sederhana dalam aktivitas sehari-hari, memberikan kemudahan bagi peserta didik untuk memahami materi yang dipelajari. Dengan demikian, lebih bermakna dan tersimpan di memori ingatan (Nurhadi, 2002: 1).

Pengembangan pembelajaran dengan materi pesawat sederhana juga dikembangkan dalam berbagai komponen pembelajaran, baik model, media, konten materi, bahkan alat peraga pembelajaran di kelas. Hal ini ditujukan agar materi "pesawat sederhana" tetap menarik dikaji di kelas dan dapat dipraktikkan di luar kelas. 
Berdasarkan uraian di atas, dipahami bahwa pesawat sederhana merupakan prinsip sesuatu yang memudahkan aktivitas manusia, meliputi tuas, bidang miring, katrol, dan roda berporos. Begitupun, kecanggihan atas perkembangan teknologi era saat ini tidak sertamerta mendistorsi peran pesawat sederhana. Sebab, benda-benda dengan menggunakan prinsip-prinsip tersebut, tetap "menyajikan" kemudahan bagi manusia.

Pembelajaran IPA secara umum berfungsi untuk mengembangkan keterampilan dalam memperoleh dan menerapkan konsep sains, menanamkan sikap ilmiah dan melatih peserta didik dalam menggunakan metode ilmiah untuk memecahkan masalah yang dihadapi, memupuk daya kreatif dan inovatif peserta didik, membantu peserta didik memahami informasi bidang ilmu pengetahuan dan teknologi (Rostikawati, 2018). Pesawat sederhana sebagai salah satu materi IPA, memiliki dampak yang dapat dirasa langsung oleh peserta didik manfaatnya. Dilihat dari kegunaannya, pesawat sederhana terbagi menjadi 4 (empat) jenis, yaitu: pengungkit (tuas), bidang miring, katrol, dan roda berporos.

Pengungkit (tuas) merupakan jenis pesawat sederhana untuk mengubah hasil dari suatu gaya. Hal ini dianalogikan kepada sebuah "batang pengungkit" dengan 3 (tiga) titik, yakni titik tumpu, titik kuasa, dan titik beban. Lebih lanjut, Marti (2012) menjelaskan bahwa pengungkit (tuas) digolongkan menjadi tiga bagian, yakni: (1) tuas kategori pertama, yakni tuas yang titik tumpunya berada di antara beban dan kuasa. Contoh: gunting, linggis, palu; (2) tuas kategori kedua, yakni tuas yang titik bebannya berada di antara titik tumpu dan titik kuasa. Contoh: gerobak dorong; dan (3) tuas kategori ketiga, yakni tuas yang titik kuasanya berada di antara titik tumpu dan titik beban. Contoh: sekop dan stepless.

Contoh gambar pengungkit atau tuas mulai dari tuas golongan I, II dan III ditampilkan dalam Gambar 3.

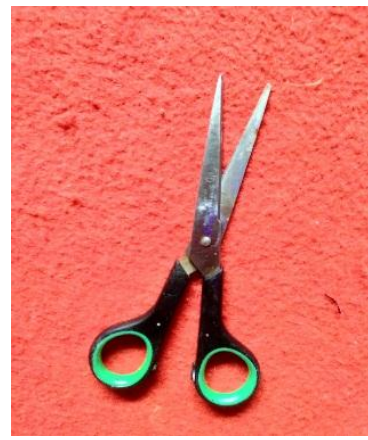

(a)

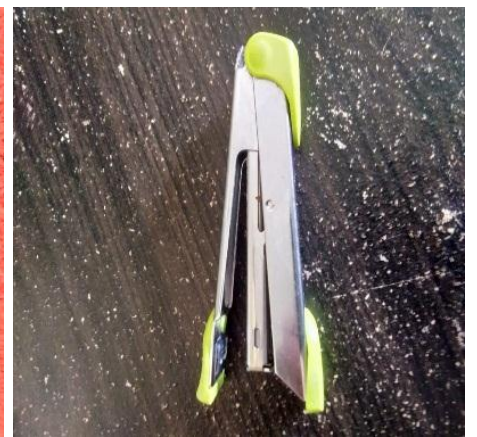

(b)

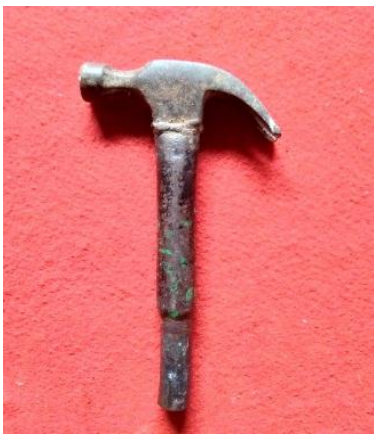

(c)

Gambar 3. Pengungkit atau Tuas, (a) Gunting, (b) Stepless, dan (c) Palu. (Dokumentasi: Assingkily)

Mencermati Gambar 3 tersebut, diketahui bahwa ketiga golongan tuas memiliki fungsi masing-masing. Begitupun, benda-benda di atas hingga saat ini masih menunjukkan 
fungsionalitasnya dalam aktivitas manusia "belum tergantikan" oleh kecanggihan teknologi informatika saat ini. Berdasarkan uraian tersebut, dipahami bahwa tuas sebagai salah satu prinsip pesawat sederhana masih menunjukkan eksistensinya melalui bendabenda jenis tuas (pengungkit). Sehingga, peran pesawat sederhana jenis tuas di era disrupsi tetap menunjukkan kebermanfaatannya dalam aktivitas manusia.

Bidang miring merupakan jenis pesawat sederhana yang digunakan untuk memindahkan benda dengan lintasan yang miring. Lebih lanjut, Marti (2012) menyebutkan bahwa bidang miring lazimnya digunakan untuk membuat baji. Baji merupakan benda yang bahan dasarnya logam atau batu, lantas satu bagian ujung baji dibuat tebal, sedangkan bagian ujung lainnya dibuat tipis sehingga menjadi tajam.

Berikut ditampilkan contoh bidang miring pada Gambar 4.

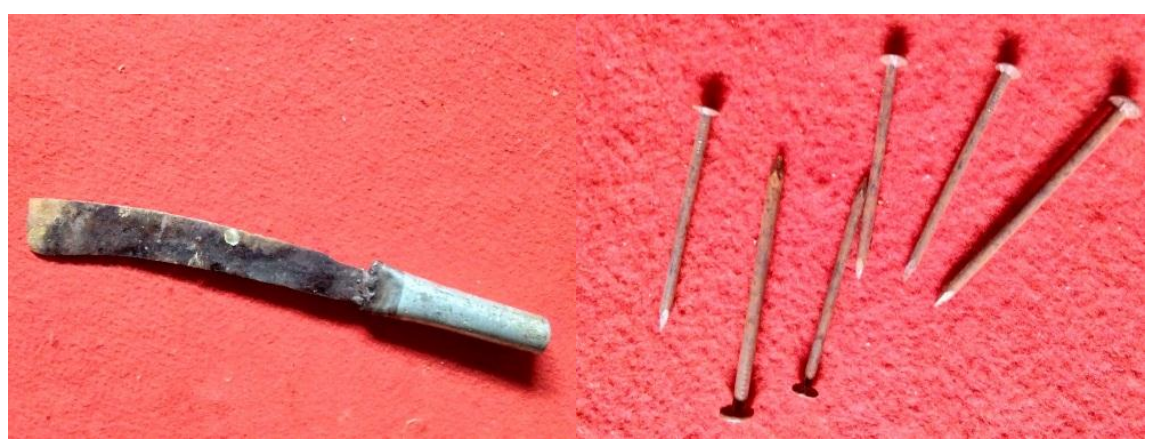

(a)

(b)

Gambar 4. Contoh bidang miring: (a) pisau, dan (b) paku. (Dokumentasi: Assingkily)

Berkaitan dengan baji, peralatan rumah tangga yang dibuat dalam bentuk baji di antaranya yakni, (a) kapak, (b) pahat, (c) paku, dan (d) pisau. Adapun kegunaannya, kapak untuk membelah atau memotong kayu. Pahat digunakan untuk mengukir patung, paku digunakan sebagai alat menempelkan benda atau pajangan di dinding, serta pisau digunakan untuk memotong (Marti, 2012).

Katrol merupakan jenis pesawat sederhana yang menggunakan rantai dan tali untuk mengubah arah gaya dari benda yang ditarik (Haryanto, 2007). Secara umum, Marti mengklasifikasikan katrol menjadi 3 jenis, yaitu: (1) katrol tunggal, yakni jenis katrol yang posisinya tak berubah-ubah. Contoh: kerekan pada sumur; (2) katrol bebas, yakni jenis katrol yang posisinya senantiasa berubah; dan (3) katrol majemuk, yakni perpaduan dari kedua jenis katrol sebelumnya yang dihubungkan dengan tali.

Lebih lanjut, contoh katrol tetap, katrol bebas dan katrol majemuk ditunjukkan dalam Gambar 5. 


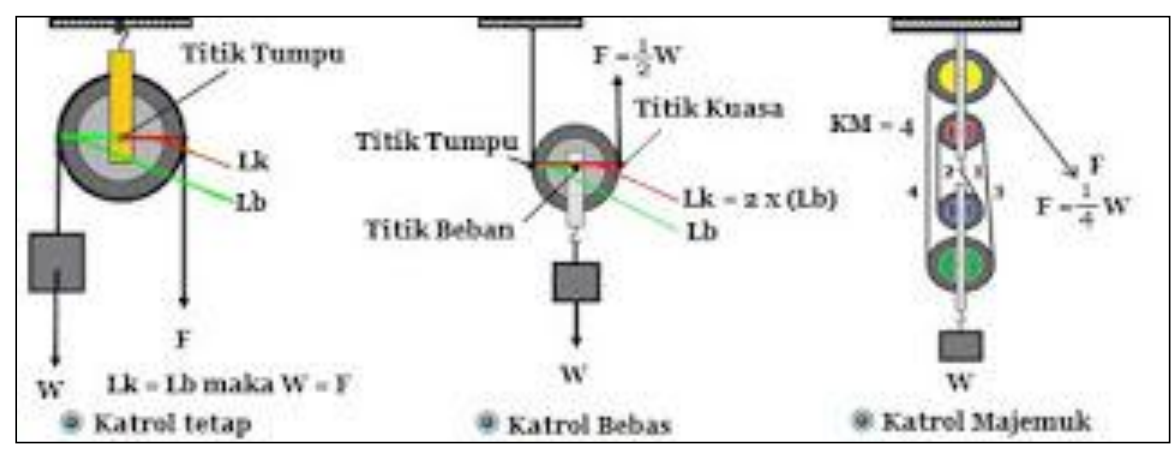

(a)

(b)

(c)

Gambar 5. (a) Katrol tetap, (b) Katrol bebas, dan (c) Katrol majemuk.

Mencermati Gambar 5 tersebut, diketahui bahwa katrol dapat meringankan aktivitas manusia. Lebih lanjut, Handayanti, et.al. (2019: 27-30) menerangkan bahwa IPA sebagai pembelajaran yang bersifat rasional dan objektif tentang semesta, mengkaji segala sesuatu di alam ini berdasarkan hasil percobaan dan pengamatan. Bahkan, katrol menjadi salah satu jenis pesawat sederhana yang mempunyai fungsi memudahkan pekerjaan manusia.

Berikut ditampilkan contoh benda dengan sistem katrol majemuk pada alat konstruksi, seperti tertera dalam Gambar 6.

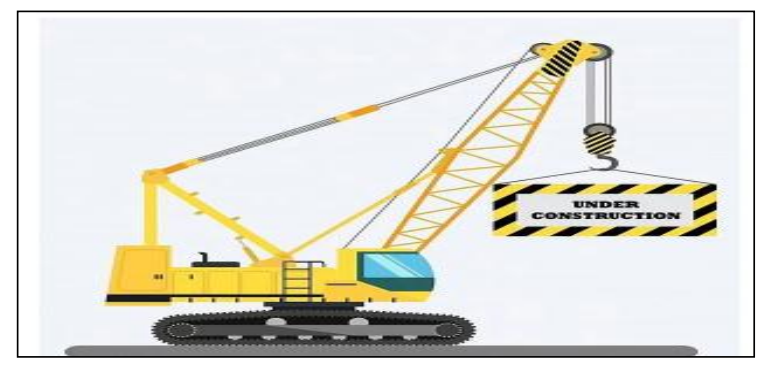

Gambar 6. Contoh Benda dengan Sistem Katrol Majemuk pada Alat Konstruksi (sumber: freepik.com)

Meskipun sistem katrol dalam upaya menimba air sumur atau telaga tidak menjadi prioritas utama, katrol tetap dibutuhkan hingga saat ini, seperti halnya penggunaan katrol majemuk untuk mengangkat benda-benda berat "bahan dasar" bangunan. Begitu juga kegunaan katrol pada alat-alat pengangkat peti kemas di pelabuhan kapal. Berdasarkan uraian tersebut, dipahami bahwa katrol sebagai salah satu jenis pesawat sederhana, tetap memberi kemudahan aktivitas manusia. Hal ini menunjukkan bahwa di era disrupsi dengan kemajuan serta kecanggihan teknologi, katrol tetap memiliki peran dan keutamaan untuk diajarkan kepada peserta didik usia dasar.

Roda berporos merupakan jenis pesawat sederhana dengan roda dan poros dalam penggunaannya. Jenis pesawat sederhana ini dapat ditemui pada alat-alat familiar dalam aktivitas sehari-hari, di antaranya motor, setir mobil, roda (ban) mobil, dan gerobak. Penggunaan roda berporos dapat memudahkan aktivitas untuk memindahkan suatu benda (Marti, 2012: 357-364). 
Berikut ditampilkan contoh roda berporos berupa ban kendaraan, seperti tertera pada Gambar 7.

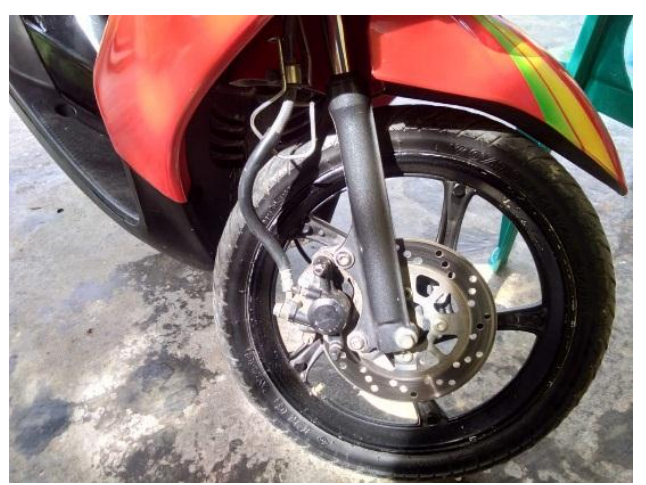

Gambar 7. Roda berporos, Ban Sepeda Motor (Dokumentasi: Assingkily)

Berkaitan dengan Gambar 7, Haryanto (2007) menegaskan bahwa prinsip kerja roda berporos yakni; (1) semakin besar roda, maka semakin kecil gaya yang diperlukan; dan (2) semakin kecil roda, maka semakin besar gaya yang diperlukan. Hal ini menunjukkan bahwa roda berporos secara prinsipil membantu aktivitas manusia.

Berdasarkan uraian tersebut, dipahami bahwa roda berporos sebagai salah satu jenis pesawat sederhana yang memberi kemudahan aktivitas manusia dalam memindahkan benda dengan beban yang berat, dari satu tempat ke tempat lainnya. Bahkan penggunaan roda berporos tetap eksis di era disrupsi ini, sebab keberadaannya terus difungsikan hingga saat ini, seperti roda ban kendaraan dan roda berporos yang digunakan pada alat pemindah barang di hotel. Untuk itu, materi pesawat sederhana berupa roda berporos tepat diajarkan kepada peserta didik usia dasar dalam pembelajaran IPA.

Kecenderungan manusia di era sekarang, lazimnya menyajikan hal yang cepat. Hal ini ditandai dengan percepatan kemajuan teknologi dan kemudahan memperoleh informasi. Mencermati ini, pendidikan sebagai salah satu aspek penting demi keberlangsungan hidup manusia mampu survive atas perubahan yang terjadi di era disrupsi.

Era disrupsi merupakan masa kemajuan IPTEK, informasi dapat diperoleh dengan mudah, dan komunikasi dapat terjalin secara cepat. Era ini menuntut adanya kolaborasi, sharing for problem solve, dan menciptakan suasana lebih fleksibel dan efisien. Istilah "dunia tapal batas" yang disematkan pada era ini, menjadikan sesuatu dapat diperoleh dengan mudah.Mencermati hal ini, sejatinya era disrupsi menghadirkan solusi baru atas kemajemukan dan kuantitas "manusia" yang begitu besar saat ini. Untuk itu, penting menakar tantangan dan mengkonstruk peluang di era disrupsi. Berikut beberapa "tantangan" yang dapat dijadikan "peluang" di era disrupsi, yakni (1) meningkatkan kualitas kurikulum pembelajaran di madrasah/sekolah; (2) menekankan pendidikan nilai sejak dini; (3) menyadari perubahan zaman; dan (4) membawa peserta didik menemukan jati dirinya. 
Kualitas kurikulum pembelajaran di madrasah/sekolah sejak satuan pendidikan MI/SD sebagai poin pertama, sejatinya membutuhkan peningkatan. Hal ini dimaksudkan agar pembelajaran yang diberikan bersifat kontekstual sesuai zaman yang sedang dihadapi peserta didik saat ini (Suhartono, 2013). Meningkatkan kualitas kurikulum merupakan salah satu visi pendidikan nasional tahun 2025, sehingga terwujud SDM yang cerdas dan kompetitif (Kemendikbud, 2010). Kreativitas dan inovasi tentu dibutuhkan dalam aktualisasinya. Untuk itu, materi IPA yang dekat dengan keseharian peserta didik ditingkatkan untuk menghasilkan produktivitas melalui konsep pesawat sederhana.

Pesawat sederhana, sejatinya memberikan konsep kemudahan beraktivitas bagi peserta didik melalui tuas, bidang miring, katrol dan roda berporos. Begitupun, kecanggihan teknologi saat ini telah menunjukkan bahwa melalui gawaipun seseorang terbantu untuk beraktivitas. Lantas, quo vadis peran materi pesawat sederhana dalam aktivitas sehari-hari di era disrupsi?

Menjawab pertanyaan tersebut, materi pesawat sederhana diarahkan pada kontekstualitas saat ini. Sehingga, esensi dari pembelajaran tercapai dengan maksimal. Sebab, benda-benda jenis pesawat sederhana senantiasa difungsikan dalam aktivitas sehari-hari, seperti halnya gunting, pisau dan lain-lain. Begitupun, dengan perkembangan zaman, kerekan penimba air dengan menggunakan katrol dan kapak untuk memotong kayu, kini mulai ditinggalkan oleh masyarakat. Oleh karena itu, di era disrupsi dengan kemajuan revolusi industri 4.0 saat ini, menjadi keniscayaan pembelajaran pesawat sederhana diarahkan kepada konsep dan praktik yang bersifat kontekstual.

Era disrupsi ditandai dengan masa yang memiliki karakteristik ketidakpastian, kompleksitas dan ambiguitas. Untuk itu, pendidikan nilai menjadi hal penting diberikan dalam setiap materi ajar kepada peserta didik, termasuk pesawat sederhana. Dengan demikian, materi ini tetap "dirasa" kebermanfaatannya ketika diajarkan kepada anak usia dasar jenjang MI/SD sebagai prinsip yang dapat memudahkan aktivitas sehari-hari.

Materi pesawat sederhana, selain memberikan bantuan untuk kemudahan aktivitas peserta didik dan masyarakat, juga tetap menanamkan prinsip usaha untuk mandiri dan kerja keras kendatipun diminimalisir beban kerjanya oleh benda-benda jenis pesawat sederhana. Berbeda halnya dengan kemajuan teknologi saat ini, terkesan memanjakan peserta didik dan para masyarakat. Sebab, kecanggihan teknologi memberikan kemudahan dan perihal yang bersifat instan dalam aktivitas seseorang. Dengan demikian, prinsip usaha kemandirian dan kerja keras semakin terdistorsi.

Mencemati paragraf di atas, pesawat sederhana menampilkan bantuan dan kemudahan aktivitas seseorang, dengan tetap menanamkan nilai-nilai pendidikan. Berdasarkan hal ini, era disrupsi dengan ditandai kecanggihan teknologi juga idealnya 
tidak sekadar menawarkan kemudahan kepada seseorang dalam beraktivitas, melainkan tetap menekankan pendidikan nilai sejak dini kepada peserta didik.

Senada dengan di atas, Megawangi et.al. (2005: 4) mengemukakan bahwa praktik pendidikan kerap kali tidak sesuai dengan tahap perkembangan usia anak (usia $\mathrm{MI} / \mathrm{SD}$ ), sehingga peserta didik "gagal" untuk berpikir kritis sejak dini dan "lemah" dalam menyikapi problematika kehidupan. Lebih lanjut, ambiguitas era disrupsi idealnya penekanan pendidikan nilai penting diberikan sejak dini kepada peserta didik.

Menurut Maksudin (2009: 1-2) ada 5 (lima) tahapan penekanan pendidikan nilai yang diberikan kepada peserta didik secara komprehensif di era disrupsi saat ini, yakni (1) identifikasi nilai (Value Identification); (2) aktivitas (Activity); (3) alat bantu belajar (Learning Aids); (4) interaksi unit (Unit Interaction); dan (5) segmen penilaian (Evaluation Segmen).

Tahapan di atas, sejatinya mengindikasikan bahwa pendidikan nilai menjadi suatu hal urgen yang patut diinternalisasikan kepada anak meski zaman berubah dan semakin canggih. Untuk itu, kelima tahapan tersebut menjadi tonggak yang dapat diperhatikan dalam mematrikan nilai melalui pembelajaran pesawat sederhana. Dengan demikian, prinsip kemudahan yang "direkomendasikan" pesawat sederhana, bukan malah menjadi aspek yang "memanjakan" dan menghadirkan kesan "instan" kepada peserta didik. Melainkan, upaya berpikir untuk memanfaatkan benda sekitar dalam memudahkan aktivitas.

Berdasarkan uraian di atas, dipahami bahwa menekankan pendidikan sejak dini merupakan aspek yang diperhatikan penuh di era disrupsi. Hal ini disebabkan dimensi kemudahan yang hadir melalui kecanggihan teknologi dan kemudahan informasi saat ini. Pesawat sederhana, sebagai materi ajar IPA yang memberikan kemudahan aktivitas manusia, sejauh ini menampilkan aspek kemudahan yang tidak bersifat instan kepada manusia. Berdasarkan hal ini, peserta didik sejak usia dasar tepat memperoleh materi pesawat sederhana untuk memahami prinsip benda-benda yang membantu aktivitas, namun tidak "memanjakan" karena bersifat instan.

Pesawat sederhana hadir sebagai bukti kemajuan cara berpikir manusia dalam memanfaatkan benda sekitar untuk membantu aktivitasnya. Kepekaan ini disebut sebagai "buah pikir" atas kesadaran adanya perubahan zaman. Begitu juga halnya dengan kecanggihan teknologi saat ini, juga merupakan "buah pikir" dari kesadaran manusia. Kesadaran akan perubahan zaman ini, sejatinya sudah dimulai sejak revolusi industri awal (1.0) hingga 4.0. Pesawat sederhana, dalam hal ini memainkan peranan sebagai konsep awal menyadari perubahan zaman.

Sebagai contoh, aktivitas manusia dalam memikul hasil panen di ladang berupa kemiri, pisang dan lainnya. Dahulu, manusia sendiri yang memikul hasil panen tersebut, 
dengan adanya gerobak sorong yang merupakan salah satu benda jenis pesawat sederhana, memudahkan manusia untuk membawa hasil panen dengan jumlah lebih besar dan waktu lebih efisien. Prinsip kesadaran akan perubahan zaman inilah yang menjadi keniscayaan diajarkan melalui materi pesawat sederhana di era disrupsi.

Jati diri merupakan sesuatu yang lazim membingungkan manusia. Sebab, seseorang dalam pencarian jati diri kerap kali mencari figur contoh yang disenangi, kemudian menirukan figur tersebut. Di samping itu, interaksi sosial menjadi hal penting dalam memenuhi kebutuhan manusia dalam mengenal jati dirinya (Tohir, 2016: 80-93). Sejatinya, jati diri seseorang tidaklah ditemukan pada diri orang lain. Untuk itu, perenungan untuk mengenali diri sendiri menjadi dimensi penting yang diedukasi pada peserta didik. Senada dengan ini, Apriliyanti et.al. (2016: 25-29) menerangkan bahwa masa remaja merupakan fase di mana manusia mengalami konflik, persoalan, kebingungan dalam menemukan jati diri dan tempat dalam ranah sosial (masyarakat).

Mengomentari hal tersebut, Basuki (2016: 117-124) menjelaskan bahwa pendekatan saintifik dalam materi pembelajaran, ditambah dengan pola pikir ilmiah, dapat mengarahkan peserta didik pada penemuan jati diri positif. Begitupun, keadaan "bingung" dalam mencari jati diri ini lazim dirasakan oleh peserta didik SLTP sederajat atau usia remaja (Hidayah, et.al., 2014). Dengan demikian, persiapan sejak usia sekolah dasar merupakan alternatif penting untuk menyikapi fase perkembangan anak.

Berkaitan dengan itu, pembelajaran IPA merupakan konsep dan praktik yang mengedukasi peserta didik secara saintis, baik melalui percobaan maupun penemuan (penelitian). Hal ini tentu mendukung peserta didik sejak jenjang MI/SD memahami sesuatu di sekitarnya secara objektif. Berdasarkan hal ini, diketahui bahwa aspek perkembangan anak dibantu melalui pemahaman-pemahaman yang rasional. Senada dengan ini, Syamsiyah \& Wedyawati (2017) menerangkan bahwa materi pesawat sederhana mengedukasi aspek objektivitas dan rasionalitas berpikir peserta didik sejak kelas V sekolah dasar. Senada dengan ini, Nuraida (2015) menyebutnya sebagai asah rasio dan intelektual anak sejak dasar. Ini menunjukkan bahwa materi pesawat sederhana membimbing anak sejak dasar untuk mematrikan pemahaman untuk memandang sesuatu secara objektif dan rasional.

Berdasarkan uraian di atas, dipahami bahwa pembelajaran IPA melalui materi pesawat sederhana menginternalisasikan nilai edukatif kepada peserta didik jenjang $\mathrm{MI} / \mathrm{SD}$. Adapun dimensi yang ditekankan yakni pemahaman dan cara pandang bahwa sesuatu tidaklah berjalan instan, namun dengan bantuan prinsip pesawat sederhana dapat memberi kemudahan aktivitas manusia. Dengan itu, diharapkan peserta didik dapat berpikir rasional, objektif, dan menemukan jati dirinya secara positif. 


\section{SIMPULAN}

Berdasarkan penjabaran tersebut, disimpulkan bahwa materi pesawat sederhana penting dan bermanfaat diedukasi pada peserta didik MI/SD di era disrupsi saat ini. Ditinjau dari perkembangan, kegunaan, dan perannya di era disrupsi, materi pesawat sederhana (tuas, bidang miring, katrol, dan roda berporos) memberikan edukasi kepada peserta didik berupa prinsip kemudahan dan tidak secara langsung. Selanjutnya, kajian pesawat sederhana relevan dengan tantangan yang dapat dijadikan peluang di era disrupsi, meliputi upaya meningkatkan kualitas kurikulum, penanaman pendidikan nilai, kesadaran perubahan zaman, dan menemukan jati diri. Begitupun, didasarkan pada keterbatasan peneliti, maka direkomendasikan pentingnya dikaji lebih mendalam terkait perbandingan data kualitatif dan kuantitatif terkait kebermanfaatan materi pesawat sederhana bagi peserta didik usia sekolah dasar. Bahkan, di waktu mendatang penting diadakan penelitian spesifik insidental terkait materi pesawat sederhana dengan sistem pembelajaran daring (online) dan/atau era covid19 saat ini.

\section{DAFTAR PUSTAKA}

Anwar, A. 2012. Meningkatkan Hasil Belajar IPA tentang Pesawat Sederhana Melalui Model Make A Match untuk Peserta didik Kelas V SDN Binturu Kecamatan Kelua Kabupaten Tabalong. Quantum: Jurnal Inovasi Pendidikan Sains, 3 (2). https://pp.jp.ulm.ac.id/journal/index.php/quantum/article/view/1360.

Apriliyanti, A., Mudjiran, M., \& Ridha, M. 2016. Hubungan Konsep Diri Peserta didik dengan Tingkah Laku Sosial Peserta didik. Jurnal Educatio, 2 (2): 25-29. http://www.jurnal.iicet.org/index.php/j-edu/article/view/62.

Asmadji, H. 2013. Pengunaan Media Pembelajaran Power Point Untuk Meningkatkan Hasil Belajar IPA Materi Pesawat Sederhana Peserta didik Kelas VC SDN Ketabang I Surabaya. Jurnal Penelitian Pendidikan Guru Sekolah Dasar, 1 (1): 1-14. https://jurnalmahapeserta didik.unesa.ac.id/index.php/jurnal-penelitianpgsd/article/view/784.

Asmawir. 2016. Upaya Meningkatkan Hasil belajar Peserta didik Melalui Metode Eksperimen pada Materi Pesawat Sederhana pada Mata Pelajaran IPA Kelas V SDN No. 3 Siboang. Jurnal Kreatif Online, 4 http://jurnal.untad.ac.id/jurnal/index.php/JKTO/article/view/3285

Basuki, S. 2016. Pendekatan Saintifik pada Penjasorkes dalam Rangka Membentuk Jati Diri Peserta Didik. Jurnal Pendidikan Jasmani Indonesia, 12 (2): 117-124. https://journal.uny.ac.id/index.php/ipji/article/viewFile/17111/10009.

Candra, D., Rosdianto, H., \& Murdani, E. 2019. Penerapan Model Pembelajaran Inkuiri Terbimbing untuk Meningkatkan Pemahaman Konsep Peserta didik Kelas VIII pada Materi Pesawat Sederhana" Variabel, 2 (1): 31-34. https://journal.stkipsingkawang.ac.id/index.php/jvar/article/view/1030. 
Diana, R., Hasanah, F., Mori, R. P., \& Mailani, N. 2020. Pendidikan Karakter Berbasis Multiple Intelligence Sebagai Desain Pembelajaran di Era Disrupsi. KoPeN: Konferensi Pendidikan Nasional, 2 (1). http://ejurnal.mercubuanayogya.ac.id/index.php/Prosiding KoPeN/article/view/1105.

Ghufron. 2018. Revolusi Industri 4.0: Tantangan, Peluang, dan Solusi Bagi Dunia Pendidikan. in Seminar Nasional dan Diskusi Panel Multidisiplin Hasil Penelitian Dan Pengabdian Kepada Masyarakat 2018, vol. 1.

Hager, G., Treibig, J., Habich, J., \& Wellein, G. 2012. Exploring Performance and Power Properties of Modern Multicore Chips Via Simple Machine Models. Concurrency and Computation: Practice and Experience, Spesial Issue Paper. https://onlinelibrary.wiley.com/doi/abs/10.1002/cpe.3180.

Handayanti, A., Handayani, S., \& Indrawati, I. 2019. Penggunaan Video Fenomena pada Materi Pesawat Sederhana Sistem Katrol untuk Meningkatkan Hasil Belajar Peserta didik di SMP Prosiding Seminar Nasional Pendidikan Fisika, 4 (1): 27-30. https://jurnal.unej.ac.id/index.php/fkip-epro/article/view/15112.

Haryanto. 2007. Sains untuk Sekolah Dasar Kelas V. Jakarta: Erlangga.

Hidayah, Z., Giyono, G., \& Widiastuti, R. 2014. Meningkatkan Kepercayaan Diri Peserta didik dalam Pembelajaran dengan Menggunakan Pendekatan Rational Emotive Therapy. ALIBKIN: Jurnal Bimbingan Konseling, 3 (1). http://jurnal.fkip.unila.ac.id/index.php/ALIB/article/view/4623.

Iman, R. 2017. Meningkatkan Kemampuan Berpikir Kritis Peserta didik dengan Model Inkuiri Terbimbing pada Materi Pesawat Sederhana. Jurnal Pendidikan Sains Indonesia, 5 (1): 52-58. http://www.jurnal.unsyiah.ac.id/JPSI/article/view/8407.

Janah, K.K. 2016. Pengaruh Penggunaan Alat Peraga Pesawat Sederhana dalam Pembelajaran IPA Terhadap Hasil Belajar. Pensa: Jurnal Pendidikan Sains, 4 (2): 1 5. https://jurnalmahapeserta didik.unesa.ac.id/index.php/pensa/article/view/14969.

Maksudin. 2009. Pendidikan Nilai Komprehensif: Teori dan Praktik. Yogyakarta: UNY Press.

Marti, N.W. 2012. Pengembangan Media Pembelajaran Pesawat Sederhana untuk Peserta didik Sekolah Dasar Berbasis Multimedia. Seminar Internasional (Peran LPTK dalam Pengembangan Pendidikan Vokasi di Indonesia), ISSN 1907-2066. file:///C:/Windows/system32/config/systemprofile/Downloads/73-181-1-SM.pdf.

Matsun, M., Darmawan, H., \& Fitriyanti, L. 2019. Pengembangan Media Pembelajaran Fisika Berbasis Macromedia Flash Topik Bahasan Pesawat Sederhana. Jurnal $\begin{array}{lllll}\text { Pendidikan Matematika dan IPA, } 10 & \text { (1): } & \text { 30-40. }\end{array}$ http://jurnal.untan.ac.id/index.php/PMP/article/view/25861.

Megawangi, Ratna, Rahma, D., Florence, Y., \& Wahyu, F.D. 2005. Pendidikan Holistik. Cimanggis: Indonesia Heritage Foundation.

Naimah, A., \& Widiati, U. 2017. Penerapan Model Pembelajaran Think Pair Share (TPS) untuk Meningkatkan Hasil Belajar IPA Kelas V SD. Jurnal Pendidikan Prasekolah, 1 (1). https://rumahjurnal.net/index.php/JPP/article/view/201.

Nash, L.K. 1963. The Nature of The Natural Sciences. USA: Little, Brown, and Company. 
Nuraida. 2015. Upaya Meningkatkan Hasil Belajar IPA Materi Pesawat Sederhana Melalui Metode Eksperimen pada Peserta didik Kelas V SDN 16 Meulaboh Kecamatan Johan Pahlawan Aceh Barat Tahun Pelajaran 2014/2015. Bina Gogik: Jurnal IImiah Pendidikan Guru Sekolah Dasar, 2 (2). http://ejournal.stkipbbm.ac.id/index.php/pgsd/article/view/75.

Nurhadi. 2002. Pendekatan Kontekstual (Contextual Teaching and Learning). Jakarta: Depdiknas.

Octafiana, W., Ekosusilo, M., \& Subiyantoro, S. 2018. Pengembangan Multimedia Interaktif pada Materi Pesawat Sederhana untuk Peserta didik Sekolah Dasar. Komunikasi Pendidikan,

168-175. http://journal.univetbantara.ac.id/index.php/komdik/article/view/131.

Oktaviana, B., Saputra, H. J., \& Arifin, Z. 2018. Keefektifan Pembelajaran IPA Materi Pesawat Sederhana Menggunakan Model Pair Check Berbantu Question Card pada Peserta didik Kelas V SDN Sukoharjo 01 Pati. Profesi Pendidikan Dasar, 5 (1): 46-56. http://journals.ums.ac.id/index.php/ppd/article/view/3852.

Permatasari, N. E., Koeswati, H. D., \& Giarti, S. 2018. Pengembangan Model Pembelajaran Problem Based Learning dan Pesawat Sederhana (Probalpena) untuk Meningkatkan Hasil Belajar IPA Peserta didik Kelas V SDN Karanganyar 01. Muallimuna: Jurnal Madrasah Ibtidaiyah, 3 (2): 116-127. https://ojs.uniskabim.ac.id/index.php/jurnalmuallimuna/article/view/1215.

Prastowo, A. 2014. Pembelajaran Konstruksivistik-Scientific untuk Pendidikan Agama di Sekolah/Madrasah: Teori, Aplikasi, dan Riset Terkait. Jakarta: Rajawali Pers.

Pratiwi, C. O., Sujana, A., \& Jayadinata, A. K. 2017. Penerapan Model Pembelajaran Inkuiri untuk Meningkatkan Hasil Belajar Peserta didik Kelas V pada Materi Pesawat Sederhana. Jurnal Pena IImiah, 2 https://ejournal.upi.edu/index.php/penailmiah/article/view/10664.

Rianto, R., Abdurrahman, A., \& Viyanti, V. 2014. Produksi Alat Peraga IPA Pesawat Sederhana Berbasis Science in Box. Jurnal Pembelajaran Fisika, 2 (1). http://jurnal.fkip.unila.ac.id/index.php/JPF/article/view/3617.

Rostikawati, E. 2018. Implementasi Metode Demonstrasi untuk Meningkatkan Pemahaman Peserta didik Mempelajari Pemahaman tentang Konsep Pesawat Sederhana Belajar Ilmu Pengetahuan Alam Kelas 5 SD Harumanis Tahun 2016-2017. Jurnal Penelitian Guru FKIP Universitas $\quad$ Subang, 1 (1). http://www.ejournal.unsub.ac.id/index.php/JPG/article/view/237/212.

Sayekti, S. 2018. Peningkatan Motivasi dan Hasil Belajar IPA Materi Pesawat Sederhana Melalui Model Teams Games Tournament (TGT) pada Peserta didik Kelas VIII SMP Negeri 2 Tarub Tahun Pelajaran 2015/2016. JPMP (Jurnal Pendidikan MIPA Pancasakti), 2 (1). https://doi.org/10.24905/jpmp.v2i1.873.

Suak, R., Said, I., \& Paluin, Y. K. 2016. Meningkatkan Hasil Belajar IPA tentang Konsep Pesawat Sederhana Melalui Metode Demonstrasi pada Peserta didik Kelas V SD Inpres 2 Langaleso. Jurnal Kreatif Tadulako, 4 (6).

Suhartono. 2013. Pengembangan RPP Berbasis Inkuiri dengan Penerapan Keterampilan Proses Sains dalam Pembelajaran Fisika. Edusains: Jurnal Pendidikan Sains dan Matematika, 12 (2). http://e-journal.iainpalangkaraya.ac.id/index.php/edusains/article/view/12. 
Suyanto. 2018. Penerapan Model Pembelajaran Snowball Throwing Berbantu Media Gambar untuk Meningkatkan Aktivitas dan Hasil Belajar Materi Pesawat Sederhana pada Peserta didik Kelas V SD 8 Gondosari. Jurnal Prakarsa Paedagogia, 1 (2). https://jurnal.umk.ac.id/index.php/JKP/article/view/3434.

Syamsiyah, N \& Wedyawati, N. 2017. Pengaruh Model Pembelajaran Kooperatif Tebak Kata Terhadap Hasil Belajar Peserta didik pada Materi Pesawat Sederhana Kelas V VOX EDUKASI: Jurnal IImiah IImu Pendidikan, 8 (1). http://jurnal.stkippersada.ac.id/jurnal/index.php/VOX/article/view/57. . (2010). Renstra Kemdikbud 2010-2014. Jakarta: Kemdikbud.

Tartiwi, C \& Wijayanti, A. 2018. Pengembangan Media Kotak Ajaib pada Mata Pelajaran IPA Materi Pesawat Sederhana Peserta didik Kelas V Sekolah Dasar. Jurnal Sekolah, 2 (4). https://jurnal.unimed.ac.id/2012/index.php/js/article/view/10678.

Tohir, D. 2016. Program Bimbingan Pribadi Sosial untuk Peningkatan Kepercayaan Diri Peserta didik: Studi Pra Eksperimen pada Peserta didik Kelas VIII MTs Al Bidayah Kabupaten Bandung Barat. Journal of Regional Public Administration (JRPA), 1 (1): 80-93. $\quad$ http://penelitian.stiasebelasapril.ac.id/wp-content/uploads/2017/07/AllFille.pdf\#page $=84$.

Widaryanto, W. 2017. Peningkatan Prestasi Belajar IPA Materi Pesawat Sederhana dengan Model Pembelajaran STAD (Student Teams-Achievement Divisions) pada Peserta didik Kelas V Semester II SD Negeri 01 Ngargoyoso Kecamatan Ngargoyoso Tahun Pelajaran 2016/2017. IJER, Indonesian Journal on Education and Research, 2 (4). http://jurnal.ijer.web.id/index.php/ijer/article/view/115.

William, R.L. 2003. Haptics-Augmented Simple-Machine Educational Tools. Journal of Science Education and Technology, 12. https://doi.org/10.1023/A:1022114409119.

Yunidar. 2018. Meningkatkan Hasil Belajar IPA pada Materi Gaya dan Pesawat Sederhana dengan Menggunakan KIT IPA Peserta didik Kelas V. Jurnal Pendidikan Tambusai, 2 (3). https://jptam.org/index.php/iptam/article/view/152.

Zakwandi, R. 2017. Analisis Konsep Pesawat Sederhana pada Pembelajaran IImu Pengetahuan Alam Berbasis Tradisi Sains Islam di Madrasah Tsanawiyah. Belajea: Jurnal Pendidikan Islam, 2 (1): 21-34. http://journal.iaincurup.ac.id/index.php/belajea/article/view/269. 